\title{
Takis Zenetos's Electronic Urbanism and Tele-Activities: Minimizing Transportation as Social Aspiration
}

\author{
Marianna Charitonidou $1,2,3$ (D) \\ 1 Chair of the History and Theory of Urban Design, Institute for the History and Theory of Architecture (gta), \\ Department of Architecture, ETH Zurich, CH 8093 Zürich, Switzerland; mchariton@ethz.ch \\ 2 School of Architecture, National Technical University of Athens, 42 Patission Street, 10682 Athens, Greece \\ 3 Faculty of Art History and Theory, Athens School of Fine Arts, 42 Patission Street, 10682 Athens, Greece
}

check for updates

Citation: Charitonidou, M. Takis Zenetos's Electronic Urbanism and Tele-Activities: Minimizing Transportation as Social Aspiration Urban Sci. 2021, 5, 31. https:// doi.org/10.3390/urbansci5010031

Received: 16 February 2021

Accepted: 8 March 2021

Published: 11 March 2021

Publisher's Note: MDPI stays neutral with regard to jurisdictional claims in published maps and institutional affiliations.

Copyright: (C) 2021 by the author. Licensee MDPI, Basel, Switzerland. This article is an open access article distributed under the terms and conditions of the Creative Commons Attribution (CC BY) license (https:// creativecommons.org/licenses/by/ $4.0 /)$
Abstract: Takis Zenetos was enthusiastic about the idea of working from home, and believed that both architecture and urban planning should be reshaped in order to respond to this. He supported the design of special public spaces in residential units, aiming to accommodate the inhabitants during working hours. This article argues that Zenetos's design for "Electronic Urbanism" was more prophetic, and more pragmatic, than his peers such as Archigram and Constant Nieuwenhuys. Despite the fact that they shared an optimism towards technological developments and megastructure, a main difference between Zenetos's view and the perspectives of his peers is his rejection of a generalised enthusiasm concerning increasing mobility of people. In opposition with Archigram, Zenetos insisted in minimizing citizens' mobility and supported the replacement of daily transport with the use advanced information technologies, using terms such as "tele-activity". Zenetos was convinced that "Electronic Urbanism" would help citizens save the time that they normally used to commute to work, and would allow them to spend this time on more creative activities, at or near their homes. The main interest of "Electronic Urbanism" lies in the fact that it not only constitutes an artistic contribution to experimental architecture, but is also characterized by a new social vision, promising to resynchronize practices of daily life. An aspect that is also examined is the relationship of Zenetos's ideas and those of the so-called Metabolists in the 1960s in Japan, including Kenzo Tange's conception of megastructures. Zenetos's thought is very topical considering the ongoing debates about the advanced information society, especially regarding the social concerns of surveillance, governance, and sovereignty within the context of Big Data. His conception of "tele-activities" provides a fertile terrain for reflecting on potential implications and insights concerning home-office conditions not only within the context of the current pandemic situation but beyond it as well.

Keywords: Takis Zenetos; Electronic Urbanism; home-office; tele-work; cybernetics; social vision

\section{Introduction}

Takis Zenetos's "Electronic Urbanism" was based on systematic speculation concerning the development of electronic applications in the realms of "tele-management," "tele-work" and "tele-services." Zenetos started developing his ideas regarding the autonomous living units designed for "Electronic Urbanism" in 1952, when he was still a student at the École de Beaux Arts in Paris. He continued to expand and modify his vision until the year of his suicide in 1977. He presented aspects of the project-from large models including several buildings to prototypes of furniture-on several occasions, such as the Exhibition of the Modern Housing Organization in Athens in 1962, and at the first Construction Exhibition at the Zappeion in 1971. Studying articles in scientific magazines of the time, such as Science, Zenetos prophesised the accelerating mutation of the living units in the cities of the future, and designed flexible systems for both buildings and infrastructures [1].

Zenetos believed that "tele-education," "tele-research" and "tele-management" would help citizens to gain access to information and knowledge on an international scale, and to 
reduce the importance of the distance between places of work and residence. In the first issue of Architecture in Greece, Zenetos published an article under the programmatic title "Problems of Construction in Greece: The City of the Future." During the following years, he also published a series of four articles under the title "City Planning and Electronics" in the same annual review in 1969, 1970, 1973 and 1974 [1-4]. All these articles were elements of one broad study. Zenetos was convinced that "Electronic Urbanism" would provide "a system of light, three-dimensional supporting structures, containing vertical gardencities and dense networks of improved telecommunications media (mainly for tertiary industry processing), freeing man from the daily necessity of transporting his body as an information-carrier to the actual location of the processing." This would become possible through the design and construction of a "continuous equilibrium cable-truss." More prosaically, the city would consist of a continuous, three-dimensional grid of stretched cables along which "the community [would] install the service networks and improve or replace them as technology evolves" [2] (pp. 112-113). In the article entitled "Town Planning and Electronics," published in the fourth issue of Architecture in Greece in 1972, Zenetos included a number of diagrams and plans of the suspended city, underscoring one of the main aims of the project: achieving the co-existence of urban structure and nature [3].

Zenetos was a member of the International Association of Cybernetics, and attended numerous congresses on the subject, such as the International Congress of Cybernetics held in London in 1969 [5]. During the late 1960s, two articles centred on the relationship between architecture and cybernetics were published in Architectural Design: Christopher Alexander's "Systems Creating Systems" [6] and Gordon Pask's "The Architectural Relevance of Cybernetics" [7]. Both texts had an impact on Zenetos's thought. At the same time, he was an avid reader of the writings of the American mathematician and philosopher Norbert Wiener and of the magazine Science, often cited in City Planning and Electronics: Parallel Structures, which was a tri-lingual edition (Greek, French and English) with the insightful subtitle "Telepolis vesus Megapolis" [8]. To better grasp the impact of cybernetics on Zenetos's thought it would be useful to bring to mind that "the 'cybernetic' concept was used by Wiener to refer to the systems which can self-regulate their behavior due to their capacity to process information they receive from their surrounding environment and whose action has an impact on the environment" [9] (p. 17).

The main interest of "Electronic Urbanism" lies in the fact that it not only constitutes an artistic contribution to experimental architecture, but is also characterized by a new social vision, promising to resynchronize practices of daily life, through the use of electronic communication systems that would allow for the transmission of data and information. Among the references used by Zenetos in the article "Town Planning and Electronics," published in the seventh issue of Architecture in Greece devoted to the themes "Leisure time, recreation, tourism" [2], are Norbert Wiener's Cybernetics, or the Control and Communication in the Animal and the Machine [10], Athelstan Spilhaus's "Ecolibrium," published in Science [11] Nicholas Negroponte's Architecture Machine: Toward a More Human Environment [12], and "Mobile Home Report," published in Architectural Design in 1972 [13]. In his writings, Zenetos also refers to Peter Cook's Experimental Architecture [14], Robin Middleton's "Disintegration" [15], as well as to the work of Richard Saul Wurman [16]. The latter chaired the 1972 International Design Conference in Aspen, which was focused on the interaction between government, transportation, schools, and social services. Among Zenetos's references [1] is Marshall McLuhan's Understanding Media: The Extensions of Man [17].

\section{Takis Zenetos's Social Vision and the Replacement of Transportation by Communication Devices}

Zenetos's social vision concerning new practices of everyday life was based on the replacement of transportation by communication devices. Zenetos argued repeatedly that the term "transportation" would have a different meaning in the future. He paid special attention "to the need for man's transportation to the very place of tertiary activities which, for the most part, consist of the transmission and processing of information." [2] (p. 116). In February 1972, in an editorial of Science entitled "Old Cities, New Cities, 
No Cities," the question was raised: "Why cannot people live wherever they wish and congregate electronically?" [18] (p. 709). A year later, Zenetos introduced his article "Town Planning and Electronics," published in the seventh issue of Architecture in Greece, devoted to the theme "The education of the architects," with this same question, paying special attention to the idea that "[m]an desires, and has a right to acquire, a 'home' in a quiet environment close to nature and at proximity to his place for work and the various public services." [2] (p. 113).

Taking as his point of departure the idea that "[t]echnology properly used may be the only short-term answer to the city's problems because it will take time to check population growth" [18] (p. 709), Zenetos argued that "[t]he remoteness between living and working areas is increasing while the urban texture is gradually being "disemboweled" for the improvement of the transportation system, which will lead, in the end, to nowhere." [2] (p. 112). Zenetos's position on this is of great significance, because it shows that he was opposed to the fetishization of speed, which was still dominant during the early seventies. His critique of the reliance of cities on transport was very apparent in the following 1973 articles: "Myths of Low-Density Living," published in Architectural Design [19], and "The Metro Does Not Solve Any Problem", published in Economy Postman [20]. In the former, Zenetos sustained that "social life cannot develop ... [in a] non-urban environment" [19] (p. 247), while in the latter he argued that "[t]he metro de facto alienates people from the urban environment" [20] (p. 24).

Zenetos was convinced that reducing the dependence of citizens on commuting would offer them variety and flexibility in terms of employment. He also proclaimed that such solutions would create more opportunities, and would enhance communication and collaboration between citizens on an international scale. He believed that, thanks to "tele-education" and "tele-research," the citizen, having eliminated the hours normally spent on transport, would be able "to devote himself to culture and advanced science" [1] (p. 116). Zenetos paid special attention to the notion of time, as is evidenced by the paper he presented at the Fifth Panhellenic Architectural Congress in Athens in 1966, where Constrantinos A. Doxiadis presented a paper as well. Takis Zenetos, in his paper, focused on his idea of a new master plan for Athens [21], supporting the "uniform distribution of activities throughout the $24 \mathrm{~h}$, [and] the abolition of the coincidence of the working hours." [22] (p. 80) This brings to mind Bolshevik economist Yuri Larin's advocation, at the Fifth Congress of Soviets in May 1929, "for what became known as the nepreryvka, the "continuous working week" [23,24].

Zenetos believed that distributing the "use of the facilities throughout the day-night cycle" would help "avoid rush hours and dead periods." In order to make this possible, he proposed the design of "multi-purpose systems," aiming to host the activities of various sectors. This would allow continuous use of the "facilities and regional centers [which would] [ ... ] give [cities] [ ... ] the necessary liveliness" [22] (p. 80). In an interview with Andreas Alexandropoulos, published in Economy Postman on 2 April 1970, Zenetos underlined that "[c]ountries where there is a population explosion or isolation of centres of activity due to geographically long distances [ ... ] will sooner or later have to deal with their impasse by electronic methods" [25] (p. 7). Zenetos remarked in his article entitled "City and House of the Future", published in Economy Postman in 1972, that the planning of the cities of the next generation should be based on the intention to reduce interventions in the natural environment as much as possible [26].

Zenetos envisioned a society inhabited by two types of citizens: the "nomads" and the "farmers." Each of these types corresponded to a different kind of living unit: the "nomad" would live in ready-made units and the "farmer" in "tissue elements that receive (individual) home and garden elements (even vegetable garden)." Zenetos claimed that in the future, the "farmer" would be the dominant type and not the "nomad." [19] Two terms

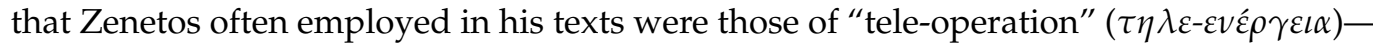
which, according to its Greek etymology, means operation from a distant location-and

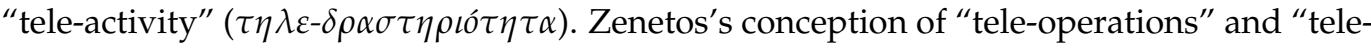


activities" brings to mind Nine Chains to the Moon, where the author refers to a "world wide dwelling services network" [27]. Useful for better grasping Zenetos's conception of "Ecumenopolis" is his article entitled "Ecumenopolis: Toward a Universal City" published in Ekistics in 1962 [28]. Zenetos's critique of the prevalence of transport infrastructure, which was dominant in the architectural debates of the seventies, and of the expansion of cities, was at the antipode of Constantinos A. Doxiadis's conception of "Ecumenopolis" [29], which focused on how to devise a "different approach" to the City of the Future, treating infrastructure as a skeleton of a body covering the entire globe and resulting from the balance between settlements, production, and nature.

Apart from the contrast between Zenetos and Doxiadis's conception of the role of transport and infrastructure, Zenetos's stance was also in opposition with that of Constant Nieuwenhuys in the sense that the former foresaw "solutions encouraging the minimum movement of man, [while] Constant [visualised] ... an urbanisation of the earth which will promote continual nomadic activity" [30]. This contradiction between Zenetos's and Doxiadis's vision is also highlighted by Panos Dragonas and Lydia Kallipoliti, in their recently published article entitled "Silence Murmur: Detached Bodies and Cities in Takis Ch. Zenetos's Electronic Urbanism", where the authors mention that "the two men confronted each other in public [ ... ] during a conference in 1966 on the problems of Athens' urbanisation". They refer to the Fifth Panhellenic Architectural Congress in Athens. At that conference Zenetos presented his "Electronic Urbanism", while Doxiadis presented his "Ecumenopolis". According to Dragonas and Kallipoliti the disagreement between the two men could be explained through Zenetos's rejection of "the deterministic predictions of population growth", which becomes evident in his declaration that "it is unacceptable in design to accept as permanent data, elements which are completely fluid" [31] (p. 18).

According to Zenetos, the living units corresponding to the needs of the "farmer" would prevail in the near future since, thanks to "the perfected means of tele-communication-telework-tele-information," "the importance of the place of residence" would progressively disappear. Zenetos was concerned about providing the inhabitant of his envisioned cities with the "freedom of isolation [combined with the] ... opportunities for social contacts and events of maximum influence." The bubbles that appear in many of Zenetos's drawings and physical models for this project were the "envelope of 'organs' serving the different functions of everyday life" [26] (pp. 10-11) (Figures 1-3). 


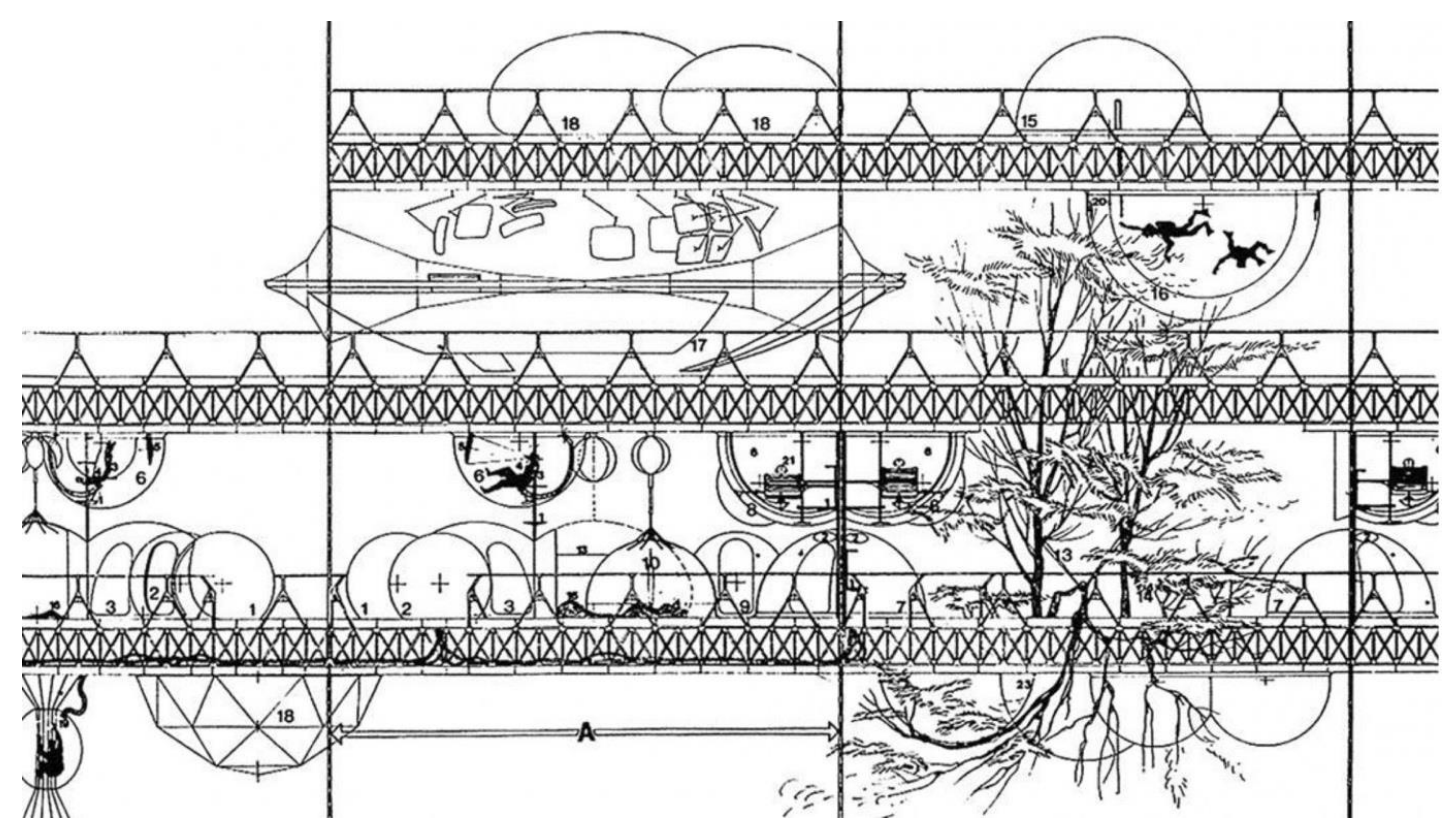

Figure 1. Takis Ch. Zenetos, section showing a partial view of the urban space grid of "Electronic Urbanism." Image courtesy of the Takis Ch. Zenetos Archive.

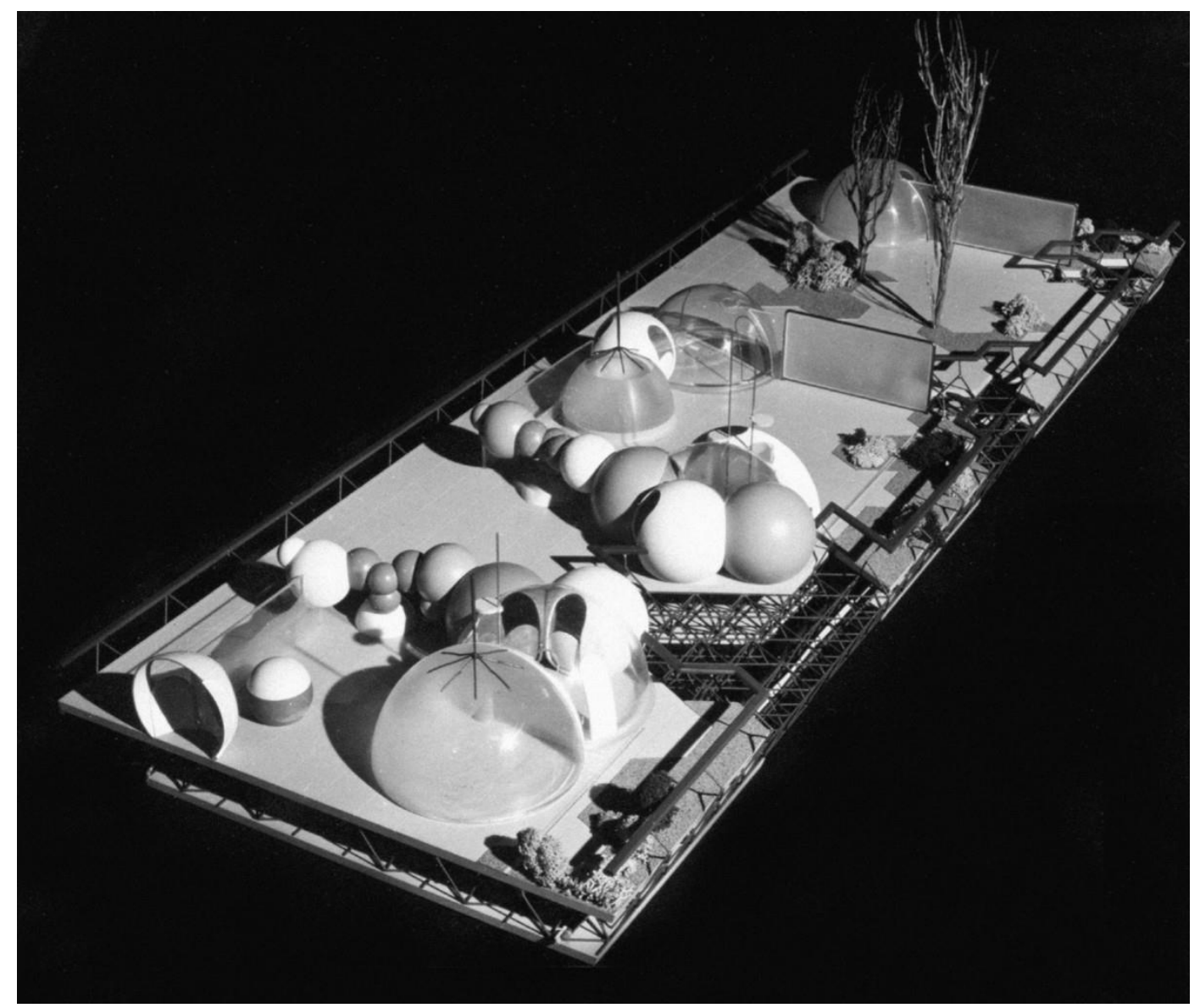

Figure 2. Takis Ch. Zenetos, physical model for "Electronic Urbanism." Part of a level, 1971. Image courtesy of the Takis Ch. Zenetos Archive. 


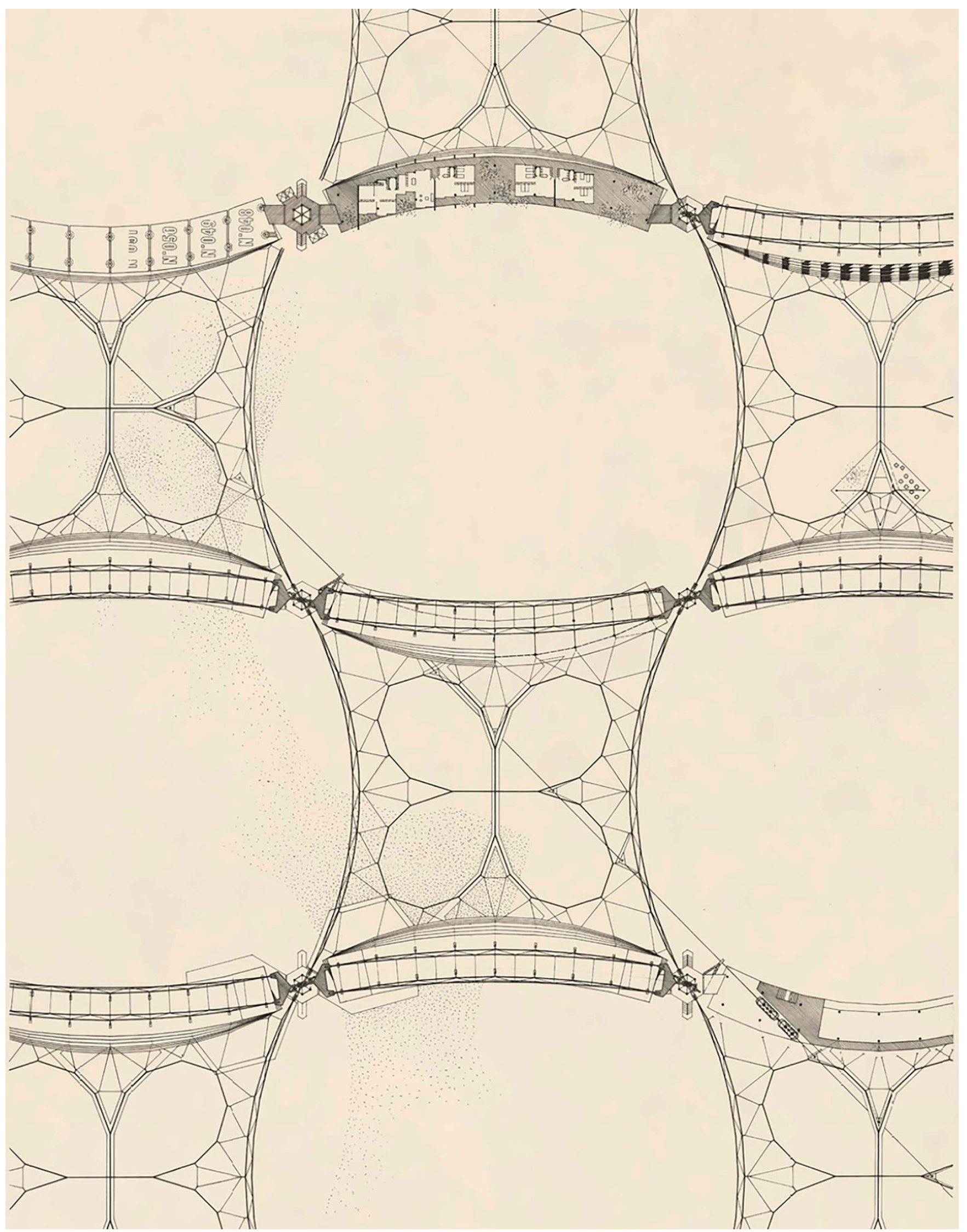

Figure 3. Takis Ch. Zenetos. Plan of the urban grid (1962). "Electronic Urbanism." Image courtesy of the Takis Ch. Zenetos Archive. 


\section{Takis Zenetos's Conception of All-Purpose Furniture}

In 1967, Zenetos, as part of "Electronic Urbanism," conceived the so-called "posture chair," "[a] mobile spinal agent of the body for every use, equipped with a remote control for tele-activities and a control center for optical-acoustic contacts, which will aid in the execution of tele-activities" [26] (Figures 4 and 5). As Lydia Kallipoliti has underscored, Zenetos's main concern was "how electronic devices and hardware developments would physically affect the urban corporeal body" [32] (p. 679). Zenetos's "Spinal Body Carrier", Michael Webb's "Cushicle" and "Suitaloon" (1966-1977), Warren Chalk's "Bathamatic" (1969), and David Greene's "living pod" (1965) [33] (p. 52) shared certain aspirations. Their main common concern was the creation of micro environments. This brings to mind Zenetos's remark that the "term housing does not mean home, of course, but sets of various operated protected macro and micro environments" [26] (p. 10).

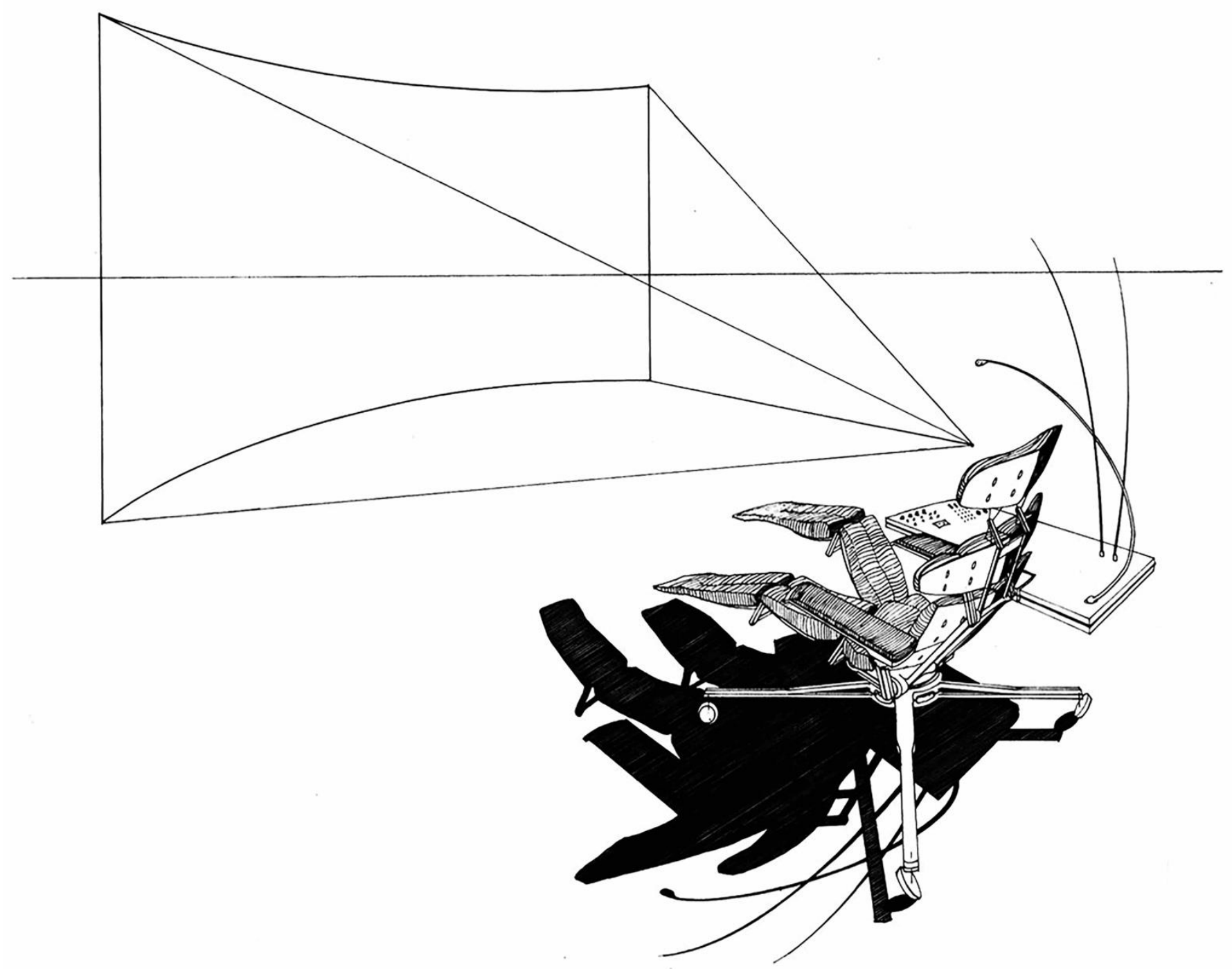

Figure 4. Takis Ch. Zenetos, Electronic City; all-purpose furniture and the communications wall-screen, 1967. Image courtesy of the Takis Ch. Zenetos Archive. 


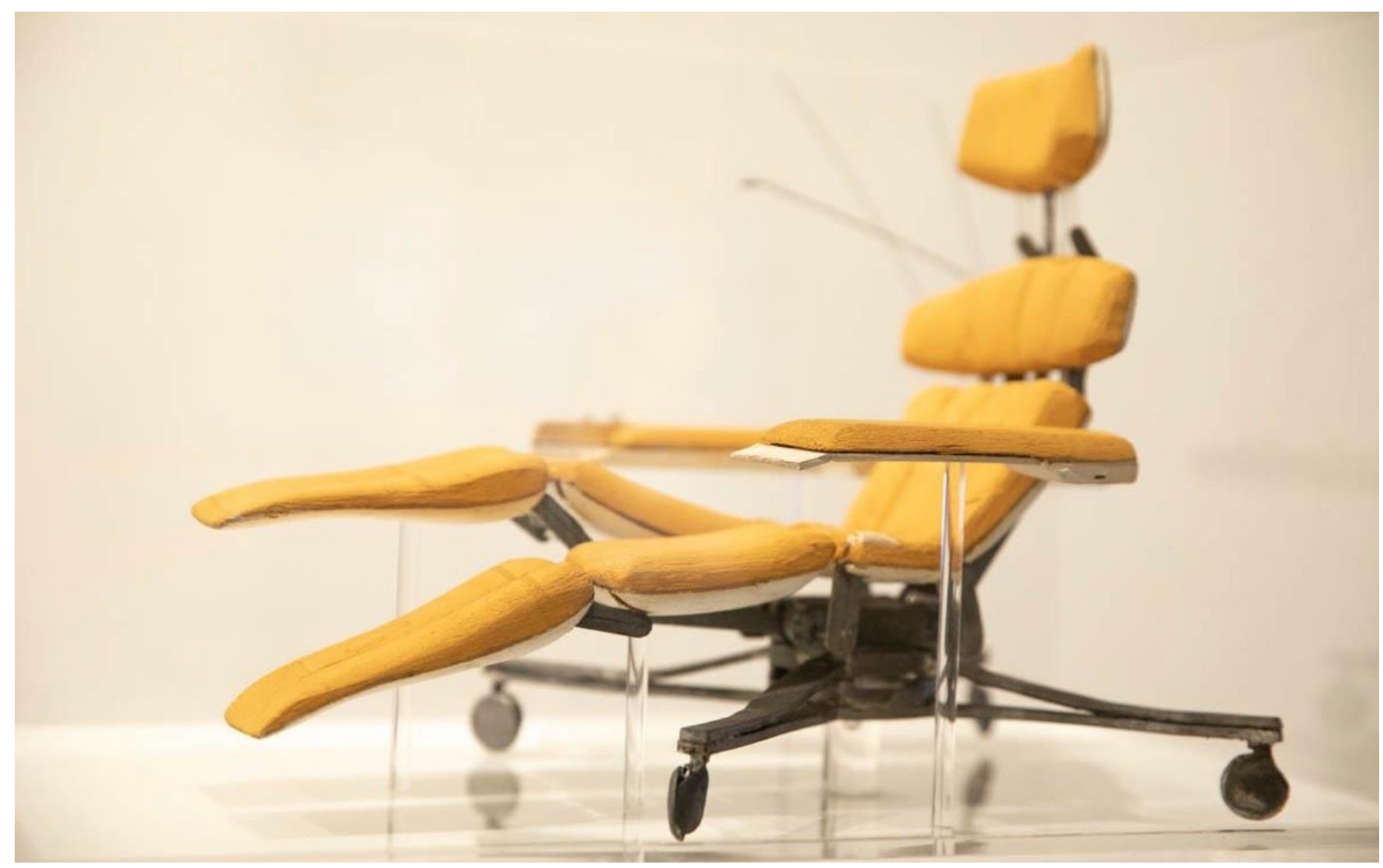

Figure 5. Takis Ch. Zenetos, physical model for the "all-purpose furniture." Image courtesy of the Takis Ch. Zenetos Archive.

Peter Cook described the "Cushicle" and "Suitaloon" as follows: "we get close to something very like man-as-a-bat, where the skin of the enclosure is dependent upon a system of vertebrae that respond very directly to the nervous system of the person within." [14] (p. 55) Furthermore, Cook, in Experimental Architecture, relates "Cushicle" to "a return to a biblical gesture, with the idea that one can 'take up one's bed and walk."' "Cushicle" was based on the idea of taking up "one's whole life-support and communications gear and enclosure (and the bed) and walk[ing]". For Cook, "Suitaloon," which had many similarities with "Cushicle," but included "a system of pipes worn around the body," was "infinitely more sociable" and was based on the "idea of the environment as a suit" [14] (pp. 116-117). In the case of "Suitaloon", as Hadas A. Steiner remarks, "biology was not technology's unifying principle as Moholy-Nagy conceived, but rather its primary motivator" [34] (p. 92). Zenetos was sceptical vis-à-vis the use of bubbles, even if many of them may be encountered in his drawings and physical models. Characteristically, he describes his bubbles as follows:

The typical elements of the living space are not 'bubbles,' such as they appear in some drawings. The bubbles are simply indicative of skins protecting the various 'organs' of everyday life, and they can be permanent or instant (alternate use during the day-night cycle), or assume any other shape or size-e.g., rigid or pneumatic balloons, polyhedrons, eventually "dilatables," depending on what will be available on the market (always, however using the minimum possible weight and quantity of raw materials). The skins could also be completely eliminated in the case of people needing no more than a simple visual or acoustic insulation, which can be achieved through special earphones and eye spectacles. [4] (p. 124)

In "City and House of the Future," Zenetos also refers to the "posture chair", describing it as a "mobile vertebrate body of all uses with remote control." Zenetos incorporated 
in this project his design for an all-purpose furniture, including the design for the so-called "posture chair," which was distinguished in October 1967 with an honourable mention at the InterDesign 2000 competition, for which he manufactured a 1/1 prototype of the chair. This competition focused on furniture that would be used in the year 2000. It is worth mentioning the fact that Zenetos described this chair as "a second human body-support." What this entailed was not so much biological as logistical, and Zenetos paid special attention to the accommodation of activities such as "telephone-contacts, telephone-work, telephone-manipulations," to use his own expressions. Zenetos described it as "an 'orthopedic' seat padded on human limbs and joints [enveloped by a] surface [consisting] ... of a sum of small hemispheres, allowing minimal contact between the lying body and the support" [26] (p. 12).

The "posture chair" would be located in a capsule providing the opportunity for several audio-visual operations. In this cell, the individual would be completely isolated and would be able to concentrate and relax. Furthermore, this same cell would include "any means [of] extending ... [one's] physical potential." One of these means would be a "wall-screen TV with the possibility of 'active participation' of the viewer [offering] ... an infinite number of tele-activities." The high-precision colour 3D image of this wall-screen TV would be "supplemented [ ... ] with the transmission of smell and touch "information", and would offer the possibility of changing environments by "tele-traveling." Through the screen, the inhabitant would be able to "watch or participate in spectacles, visit a house of friends (on the other side of the earth), do shopping." Zenetos claimed that the "free time that will result will give a new dimension to relations between cohabiting individuals, which will be heard by the quiet contemplation of the essence of things" [4] (p. 123).

\section{4. "Electronic Urbanism" vis-à-vis the Shifts in Social Structures}

The main aim of Takis Zenetos's "Electronic Urbanism" was to minimize intervention on the ground level, on the one hand, and to achieve the "coexistence of the natural element with a high-density urban environment," on the other. Zenetos took into account citydwellers' desire to inhabit a dense and vivid environment offering them "any kind of service in the shortest possible distance" [26] (p. 11). It is important to highlight that, for Zenetos, "[t]he tele-activities ... [would offer] local communities the opportunity to reorganize themselves in terms of social and cultural objectives" [35] (p. 21). Zenetos's reorientation of city design and living units means that working from home results in the restructuring of society. More specifically, he conceived "Electronic Urbanism" in conjunction with a shift in social structure, that is to say in conjunction with "an unprecedented mobility in its structure and in the independence of its members" [26] (p. 11), to borrow his own words. Yona Friedman's "Ville Spatiale" and Zenetos's "Electronic Urbanism" shared the intention to enhance mobility and flexibility, and this is evident in the ways they designed their suspended city. Friedman, in "Towards a Coherent System of Planning," notes that his main objective was to conceive design methods for infrastructure that would host living units, offering "the mobility of units," and the "possibility of any grouping and regrouping of a cluster of units." The most significant meeting point of the thought of Friedman and Zenetos was their shared notion that architectural and urban design could promote the "free utilization of the earth level and the space under the structure" [36] (p. 372).

The questions Zenetos addressed through his work on "Electronic Urbanism" were already present in his reflexions during his studies at the École des Beaux Arts in Paris. This makes us wonder what the role of the Parisian scene was within the development of his ideas, and particularly of the design strategies that led to the "individual living units" of the city of the future. Zenetos's interest in "individual living units" was not only at the heart of the reflection developed in his City Planning and Electronics: Parallel Structures, but also at the core of his graduation project at the École des Beaux-Arts in Paris, completed in 1953, and of his "Cable City" project for a suspended city (ville suspendue), designed in 1961 (Figures 6-8). The title of his graduation project-“Micropolis: Unité $\mathrm{d}^{\prime}$ habitation autonome"-demonstrates his fascination with the re-invention of the notion 
of the living unit. Zenetos's "Electronic Urbanism", which consisted of a network of individual living units spread over a vast infrastructural domain, presents many affinities with various projects of suspended megastructures, such as the utopian urban network over Paris designed by Yona Friedman, the Plug-in City by the British group, Archigram, and the New Babylon by Constant Nieuwenhuys. In the 1964 issue of the journal Archigram, one can see the Plug-in City by Archigram, New Babylon by Nieuwenhuys, and a sketch of a floating megastructure by Zenetos. In the page featuring these drawings, it reads:

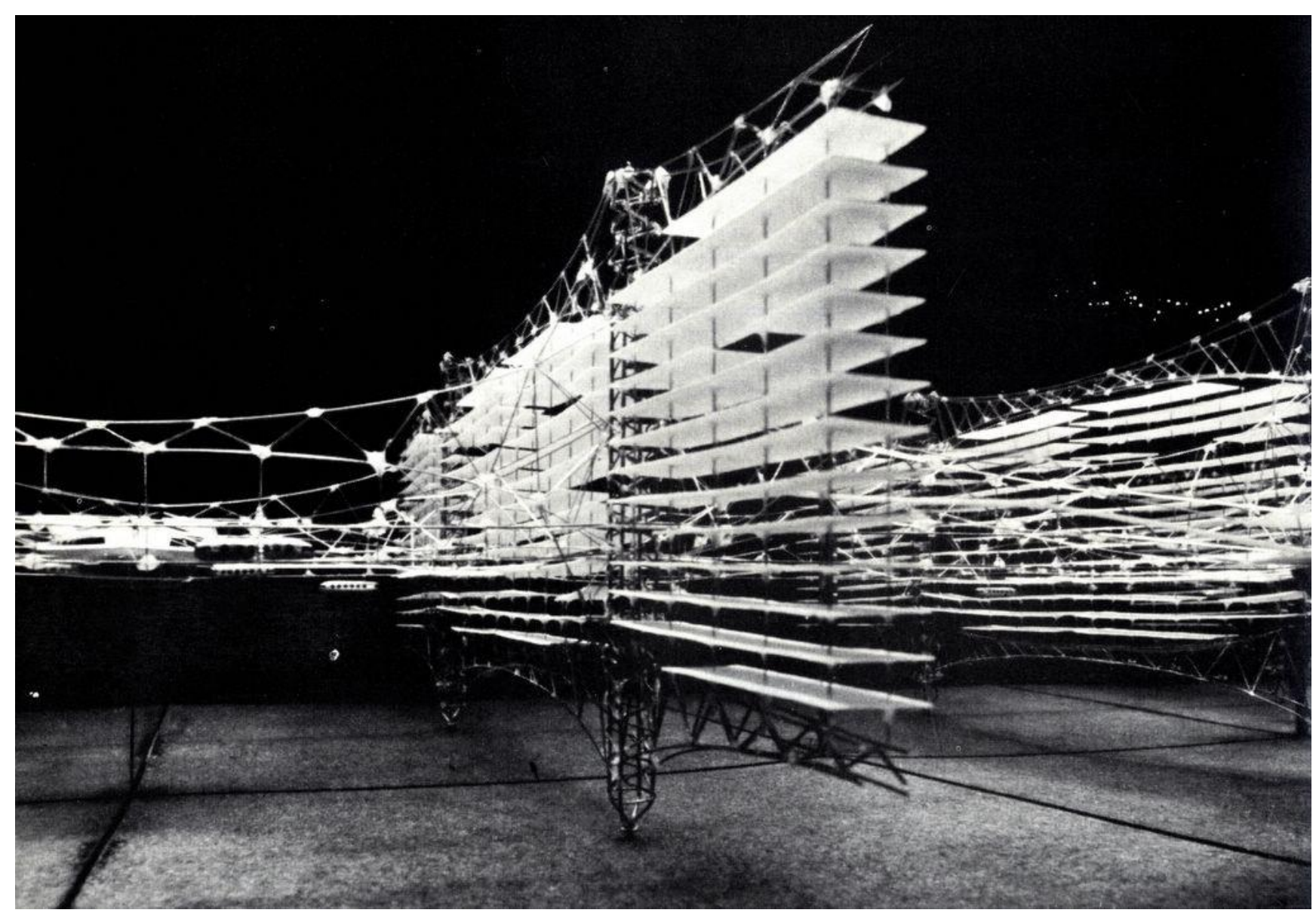

Figure 6. Takis Ch. Zenetos, physical model for the "Suspended city" ("Ville suspendue"), 1961. Image courtesy of the Takis Ch. Zenetos Archive.

Within the big structure, almost anything can happen. This is in effect, the brief from which Plug-in City develops. In T.C. Zenetos's city project (detail of which is shown bottom left) there is a system of trays slung within a wire network. Constant, in a part of New Babylon (bottom right) uses a close-knit diagonal net to establish platforms and building-objects. The big structure in Plug-in City is at the other end of the scale in that it incorporates lifts and services within the structure tubes. It controls the discipline of the whole city, but on a very large scale. [37]

As Dimitris Papalexopoulos and Eleni Kalafati highlight, Zenetos challenged Archigram in the sense that he "pursues a more modern concept of space, in which new technologies are rationally incorporated, [and] [t] he plug-in is not designed separately from the 'connected'" [35] (p. 14). Although these projects have affinities as far as their morphology is concerned, they differ in terms of vision. More specifically, what distinguishes Zenetos's approach from those of Archigram are his social concerns, which becomes evident in his following statement: "Man desires and has the right to acquire a 'home' in a quiet environment, close to nature and close to his place of work and the various public ser- 
vices" [2] [p. 113]. The special attention he paid to the impact of "Electronic Urbanism" on society's structure is evidenced not only by the insistence on the impact of urbanism on society's mutation, but also by his reference to the works of sociologists, such as American urban sociologist Gerald Dale Suttles, and especially in his book The Social Construction of Communities [38].

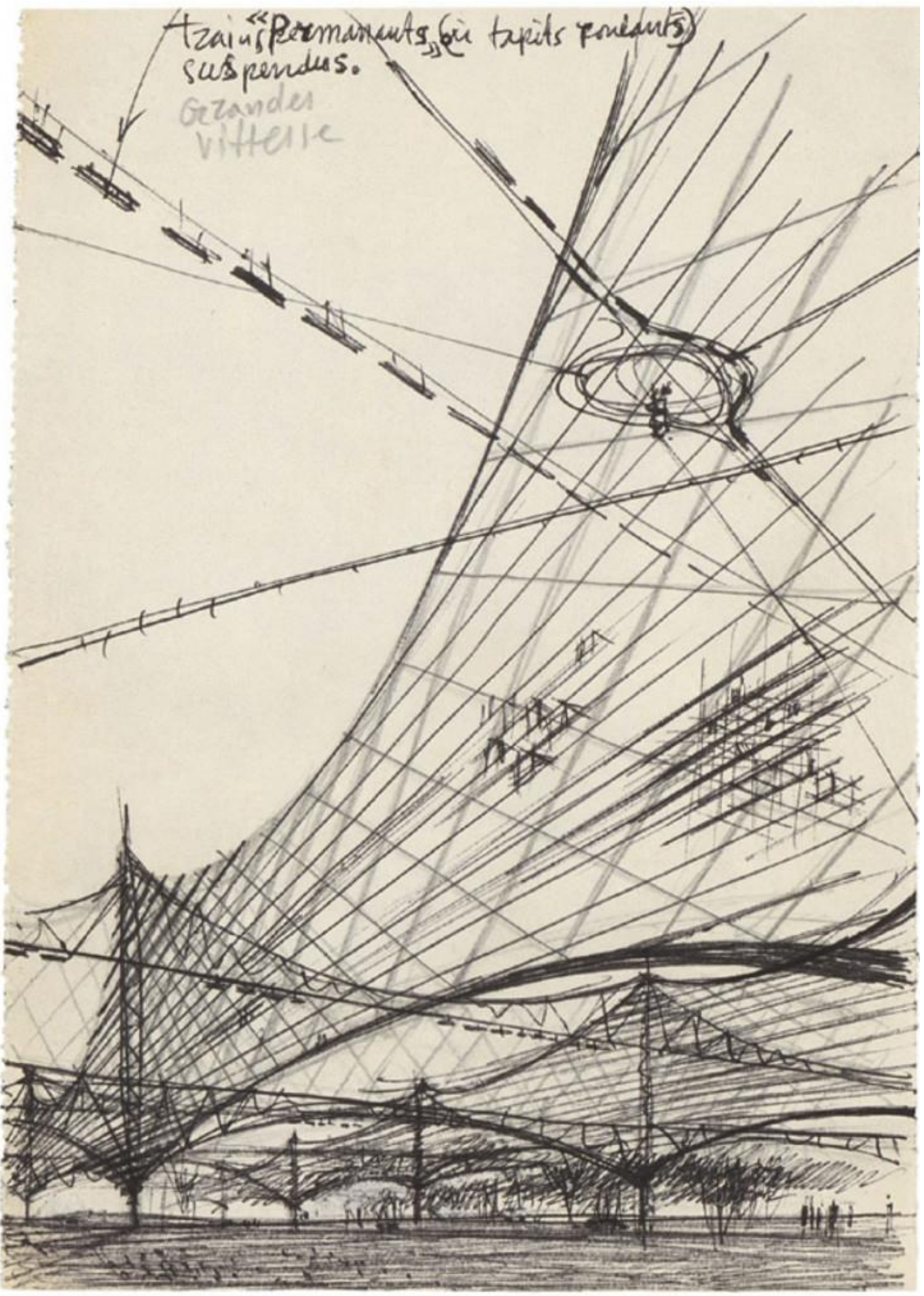

Figure 7. Takis Zenetos, sketch for the "Suspended city" ("Ville suspendue"), 1961. Image courtesy of the Takis Ch. Zenetos Archive. 


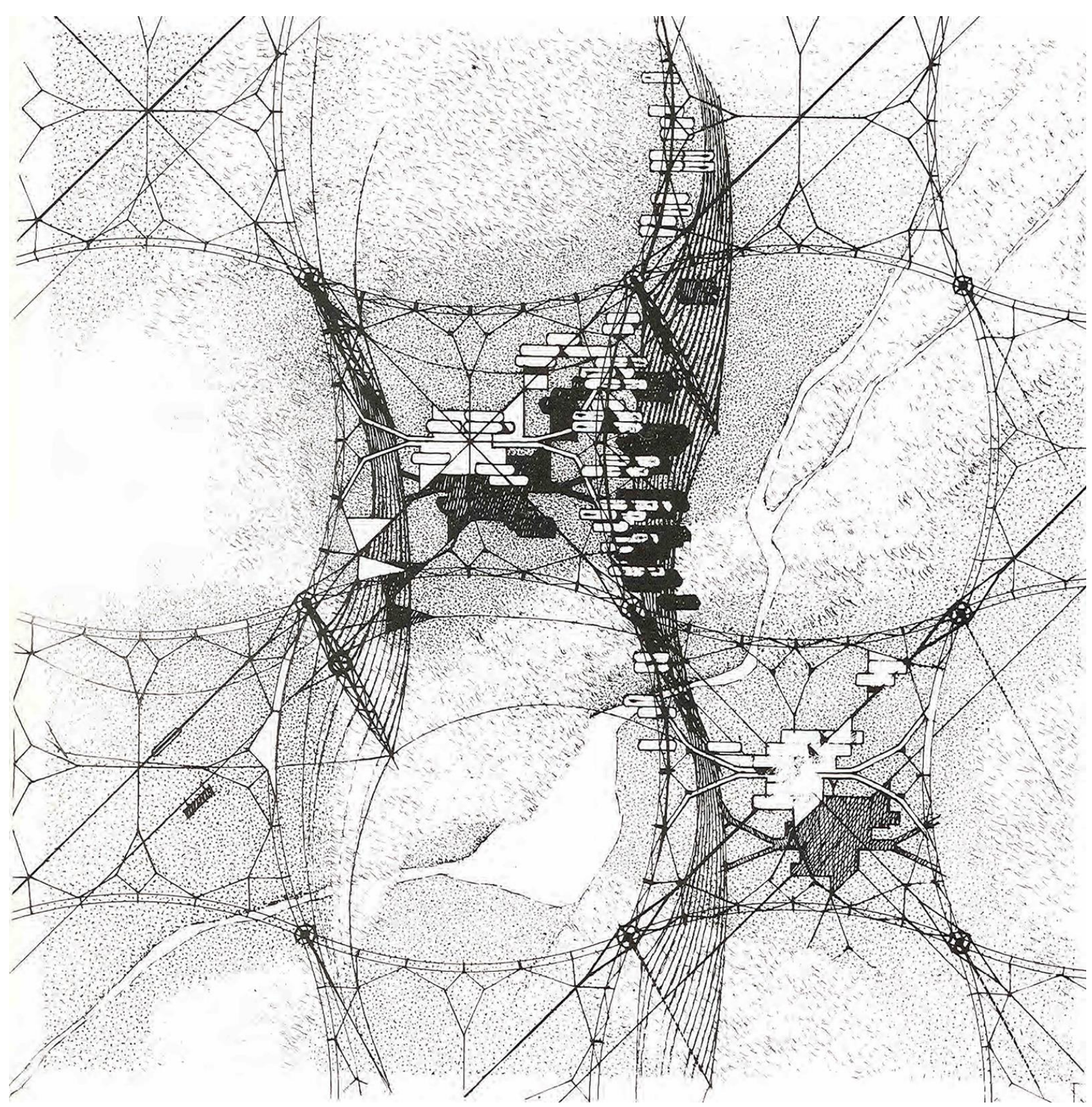

Figure 8. Takis Ch. Zenetos, general plan for the "Suspended city" ("Ville suspendue"), 1961. Image courtesy of the Takis Ch. Zenetos Archive.

\section{Takis Zenetos's Electronic Urbanism versus Metabolists' Megastructure}

Apart from comparing Zenetos's vision with the views of his peers in Europe concerning the use of advanced technologies for the design of megastructures of structures extending above the existing urban fabric, it would be thought-provoking to juxtapose his approach to that of the so-called Metabolists in the 1960s in Japan including Kenzo Tange's conception of megastructures. As Tomoko Tamari remarks, in "Metabolism: Utopian Urbanism and the Japanese Modern Architecture Movement", "the Metabolists sought to promote the idea that the city could be regarded as a supra-individual organism which could generate its own autopoetic momentum/force". Tamari also notes that the "Metabolists sought to establish a higher and more influential social status for architects who could reinvent the concept of modern architecture" [39] (p. 203). Zenetos's ideas as those of the 
Metabolists are closely related to the contradictions between concept of megastructure with a central administration system and the citizens' autonomy. A common point between Zenetos's approach and that of the Metabolists is their concern about the social aspects of architecture, which is not at the centre of Archigram's work. Zhongjie Lin relates the social concerns of the Metabolists to a "revival of Marxist ideology in Japanese intellectual circles" [40] (p. 608) during that period.

To grasp the key issues of the Metabolists' approach, it would be useful to bring to mind the etymology of two terms: metaborisumu and shinchintaisha. The former, as Tamari highlights, refers to metabolism, while the latter refer to "the function of metabolism". These terms served to express their understanding of the city as "an organic entity which has the function of metabolism" [39] (p. 206). According to Raffaele Pernice, "Metabolism' refers to the biological phenomenon of the cellular metabolism, as the result (summa) of chemical changes that convert the nutritional elements in energy and the chemical complexes in cellular material" [41] (p. 362). As manifesto of the Metabolists is considered Metabolism: The Proposals for New Urbanism [42], which was presented at the World Design Conference in Tokyo in 1960.

Both Zenetos and the Metabolists conceived the city as a building. In this sense, they shared their interest in the megastructure. However, Zenetos very often underscored that he was supporting an architectural and urban planning approach based on the design of as light as possible structures. During the late 1950s and the early 1960s, the Metabolists designed several projects that could be compared to Zenetos's "Electronic Urbanism". Among them I could refer to Kiyonori Kikutake's "Tower Shaped Community" (1959) and "The Marine City" (1963), Kisho Kurokawa's "Helix City" (1961) and "Agricultural City" (1960), Arata Isozaki's "City in the Air" (1961) and Kenzo Tange's "Plan for Tokyo 1960". A characteristic of the megastructures of the Metabolists that is close to Zenetos's conception of living units is the insistence of the synthesis of an assemblage of jointed-together units. Another affinity between Zenetos's approach and that of the Metabolists is their understanding of the cities as organic processes and self-organising resilient systems [43] (p. 362). Characteristically, they declared in their manifesto:

We regard human society as a vital process - a continuous development from atom to nebula. The reason why we use such a biological word, metabolism, is that we believe design and technology should be a denotation of human society. [42] (p. 3)

Both Zenetos and the Metabolists were enthusiastic about the incorporation of advanced technological devices in their architecture. Zenetos as Kenzo Tango very often used a "bio-informational language" and "biology, symbiosis, cyborgs, cybernetics, and prosthetics" were at the centre of their thought and discourse [44] (p. 106). Zenetos and the Metabolists placed particular emphasis on the exploration of architectural and urban design strategies that provide the possibility of architecture and urban planning to adapt to the shifts in the social structure of the city. Similarly, Cedric Price's approach to design was characterised by an understanding of architecture as part of an extensive social and environmental system, or ecology, that influences the inhabitants' mutual interactions and their relationship with their physical surroundings [45]. This becomes evident in several of his projects as, for instance, the Inter-Action Centre (1970-1977), which is a completed project for a community centre commissioned by Ed Berman and the Inter-Action Trust. The vision on which the Inter-Action Centre was based on the intention of the architect to enhance the interaction between material resources, technology, and individual action. Cedric Price was particularly interested in the design of solutions promoting flexible, prefabricated, and short-life housing, and in what he called "life patterning" potential within broader social, economic, and historical contexts.

A paradox that characterizes the approaches of the Metabolists and has been highlighted by Tamari is the fact that "[a]lthough they embraced people's autonomy and freedom in the future society, their major concept, megastructure, was accompanied by the idea of a central administrative system where professional architects could play a key role in designing and controlling urban life" [39] (p. 214). We could claim that this tension is 
also present in Zenetos's work. According to Raffaele Pernice, the Metabolists "promoted the architecture of mega-structure by Metabolist group [because they mistrusted] [ ... ] the policy of government and local administrations in facing the chaos of the cities[, on the one hand, and due to their belief in] [ ... ] the possibilities given by the new technologies" [41] (p. 362). A seminal book that is useful for comparing how different architects and architectural groups conceived the notion of megastructure during the 1960s and the 1970s is Reyner Banham's Megastructure: Urban Futures of the Recent Past originally published in 1976 [46,47]. Archigram's early years were also characterised by an enthusiasm for megastructures. However, they might have realised that their designs relied on the existence of "a team of trained experts to manage and operate the cranes, trains, and other infrastructural appurtenances that accommodated [the] [ ... ] inhabitants' ludic wishes" [48] (p. 182), and, they progressively left behind their optimism towards megastructures.

\section{Reinventing the Relationship between Nature and Technology}

As Simon Sadler remarks, both "New Babylon and Plug-in City were ... devised to prompt circulation and accelerate the city-in-flux." [49] (p. 60) The same issue of Archigram in which Zenenetos's sketch was included was devoted to "Metropolis" and featured drawings by architects such as Yona Friedman, Hans Hollein, Arata Isozaki, Paul Maymont, Frei Otto, Eckhard Schelze-Fielitz, Paolo Soleri, and Kenzo Tange [34] (p. 95). Comparing Frei Otto, Yona Friedman, and Takis Zenetos's conception of the city of tomorrow's living units and their relationship to tele-working and home-office conditions is useful in order to better grasp what was at stake during this period, as far as the conception of the relationship between nature and technology is concerned. Zenetos was sceptical vis-à-vis Mies van der Rohe and Le Corbusier's understanding of living units, and blamed them for failing to establish architectural and urban design strategies capable of going beyond the division between interior and exterior conditions. This brings to mind Tristan Tzara's elaboration of the term "intra-uterine architecture" as a reaction against Le Corbusier's "machine for living". [50] In Takis Ch. Zenetos, 1926-1977, the Greek architect underscores his disapproval of his predecessors' understanding of living units:

I did not imitate Mies van der Rohe, much less Corbu who, while giving interior space a unity, created a definite boundary between interior and exterior, thus making handsome boxes. My own effort has been to integrate the interior with the environment, with no clear dividing line between the two. For the sake both of the resident himself and the man in the street. [51] (p. 6)

This reimagined osmosis between nature and technology is related to a new conception of both health and hygiene. In the case of Zenetos's conception of "Electronic Urbanism," this becomes evident in the way he conceptualized the "private hygiene cell", which included a "catholic shower" spraying, but also in the way he conceptualized the nutritional functions of the citizens of this superstructure. More specifically, Zenetos, in his endeavour to holistically address the various aspects of daily life in his re-invented society, also included the re-invention of inhabitants' nutritional habits, conceiving and even designing a "laboratory for the composition (and decomposition) of consumer goods." Some other elements also related to issues of health and hygiene are his conception of an "air screen of controlled density through refraction particles of various radiation groups," "gym equipment for bodily exercise," and a "support for plant climbers" [4] (p. 126).

Frei Otto founded the Institute for Lightweight Structures (ILEK) (Institut für leichte Flächentragwerke) at the University of Stuttgart that same year, in 1964. Its German nickname was Spinnerzentrum. A total of four years earlier, the biologist Johann Gerhard Helmcke cofounded a research group under the name "Technology und Biology." Frei Otto collaborated with biologists Ulrich Kull and Johann Gerhard Helmcke for "Occupying and Connecting", which was published in 2009 but was written in 1964. This work constituted an endeavour to envision "a new way of looking at town planning as a field" through a close analysis of "the processes of occupying and connecting in nature and technology." In order to translate their observations into design tools, Otto, Kull, and Helmcke focused 
their analysis on the "nets, paths, connections, [and] nodes [ ... ] that run all through our natural and technical environment, creating it and influencing it" [52] (p. 6). As Daniela Fabricius highlights, "[f]or Otto and Helmcke the world of nature and technology became subsumed under a general understanding of structure" [53] (p. 1261). Otto's intention to envision technology and nature as an osmosis is apparent in his conception of the so-called Ökohaus (literally Eco-House), which was a green vertical cocoon he designed in the early 1980s. Characteristically, Otto remarked in 1984 that "[e]ach man can create [his] ... own individual environment" [54].

Frei Otto's article "The City of Tomorrow and the Single-Family House" ("Die Stadt von Morgen und das Einfamilienhaus") is particularly useful for understanding his conception of the living units of the city of tomorrow. In this article, Otto underscores that "[t]he creation of climates favourable for life is ... the main task of every designer of the environment" [55] (p. 647). The concern about climatically controllable environments was also at the core of Zenetos's thought, as becomes evident when he remarks that the "entire environment (meaning the climatically controlled space) will be "separated" from the outdoors with air screens containing reflection particles of adjustable density, ensuring the desired degree of insulation from sun radiation" [4] (p. 124).

The fact that both Zenetos and Friedman very often employed the term "parallel city" invites us to wonder what are the common points between Zenetos's "Electronic Urbanism" and Friedman's "Ville Spatiale." Yona Friedman was interested in providing "continuous flexible space." In "Towards a coherent system of planning," he remarked that "we need to find a system of physical planning, that yields to transformation if it becomes necessary" [36] (p. 371). Friedman's intention to conceive a system able to respond to mutations brings to mind Zenetos's conception of architecture and urban planning as actors aiming not only to respond to, but also enhance the transformations of, the structure of society. In another article, also published in Architectural Design, entitled "Towards a Mobile Architecture," Friedman recognized the role of digital technology for tackling the problems related to urban planning, remarking that "[m]ost of the complicated problems of today are resolved by electronic computers." He was interested in reshaping the role of "agronomists, production engineers [and] urbanists", who, for him, were the "technicians of everyday life." He wished to coordinate "the technicalization of society, and those extant sentimental or human binds which are affected by this technicalization" [56]. Yona Friedman's concern about the necessity to conceive architectural solutions able to adapt to the shifts of society becomes evident when he uses the term "mobile urbanism" in order to refer to the strategies based on "the search for techniques allowing the construction of large units within which an infinite flexibility is required; techniques allowing the provision of supplies (water, energy, sewage disposal) capable of rapid alteration and reutilization; techniques using elements, inexpensive, simple to erect, easy to transport, reusable" [57] (p. 48).

The publication of Yona Friedman's "Ein Architektur-Versuch" in Bauwelt played an important role in his relationship with Frei Otto, since the latter wrote to Friedman after reading it [58]. Thanks to a letter he had sent to Alfred Roth, Friedman had the opportunity to attend the tenth Congrès internationaux d'architecture moderne (CIAM) in Dubrovnik in 1956, where mobility was one of the topics addressed within the framework of the exchanges on the Habitat, the main theme of the congress. In "The Settlement Revolution," a statement he presented at this congress, he underlined the importance of the users, claiming that "[s]ettlement problems cannot be solved by others than by the effective users." [57] (p. 379). Friedman's concern about the "effective user" is related to a significant mutation of the epistemological scope of architecture and urban planning, which cannot but be understood in conjunction with the re-invention of home-office conditions. Within this context, architecture and urban design strategies are called to respond to distance working, and to the needs related to "tele-work", "tele-communication", and "tele-education."

Yona Friedman's manifesto "Mobile architecture," published in 1958, should be interpreted in connection with this new epistemological scope of architecture and urban planning. Friedman, who lived in Paris from 1957 on, founded the Groupe d'études 
d'architecture mobile (GEAM), which existed from 1958 to 1962. Among its members were Paul Maymont, Frei Otto, Eckhard Schultze-Fielitz, Werner Ruhnau, and D. G. Emmerich, all of whom are frequently referenced by Zenetos. As Dimitris Papalexopoulos and Eleni Kalafati remarked, Zenetos, in his correspondence with Frei Otto, criticized Yona Friedman, and believed in solutions based on lighter structures than those proposed by Otto [35]. Rem Koolhaas's following remark, in "Bigness or the Problem of Large," is useful for understanding Zenetos's critique of Friedman:

Europeans had surpassed the threat of Bigness by theorizing it beyond the point of application. Their contribution had been the "gift" of the megastructure, a kind of allembracing, all-enabling technical support that ultimately questioned the status of the individual building: a very safe Bigness, its true implications excluding implementation. Yona Friedman's urbanisme spatiale (1958) was emblematic: Bigness floats over Paris like a metallic blanket of clouds, promising unlimited but unfocused potential renewal of "everything," but never lands, never confronts, never claims its rightful place criticism as decoration. [59] (p. 504)

Zenetos's intention to design light structures and not megastructures is evidenced by his claim that the "structure of the city and the house of tomorrow will have to be ephemeral and, as much as possible immaterial." Characteristically, he noted in 1969: "Even after the 'tele-operation' of tertiary production has been established, the urban grip will have to be continuously adapted to allow for social structure mutations and improved service systems" [4] (p. 124).

\section{Conclusions}

Takis Zenetos's critique of the prevalence of transport infrastructure, which was dominant in the architectural debates of the seventies, and of the expansion of cities, was at the antipode of Constantinos A. Doxiadis's conception of "Ecumenopolis," [28,29] which focused on how to devise a "different approach" to the City of the Future, treating infrastructure as a skeleton of a body covering the entire globe and resulting from the balance between settlements, production, and nature. Besides his interest in the broader aspects of urban planning, Zenetos paid particular attention to the complexity of the psychological and physiological needs of citizens within such conditions, as is evidenced by his "all-purpose furniture" design. Zenetos's chief concern was to allow users to become as creative as possible. His flexible superstructures are characterized by an integration of nature in the built environment. Furthermore, he understood technological innovation as a means permitting socio-political changes. His insistence on the significance of immaterial architecture was based on his conviction that "the man of the future [would] ... make it possible to use immaterial systems for the creation of his environment." He believed in the force of "simulated situations" and in the capacity of thought tele-emission to "materialise...desired situations" [4] (p. 125). His main concern was to design in a way that would extend humans' natural abilities as much as possible. Regarding the social implications of Zenetos's vision, it would be useful to shed light on his remark that "[e]ach consumer's 'credit potential' will be determined by a quotient of several coefficients, in order to avoid class segregation - which, in fact, would be reduced to the minimum ... by constant education, the use of biocorrective media to improve the defective idiosyncrasy of different persons." This remark indicates that he believed in a direct connection between biology and social behaviour. This also implies a specific understanding of health. An echo of the current situation of the pandemic breakout and the need to sterilize one's body and the indoor environment can be found in Zenetos's suggestion that inhabitants "[o]n their return to the living spaces ... would discard their coveralls at the 'entrance cell,' to enter the 'controlled environment' after being spray-cleaned" [4] (pp. 124-125). This demonstrates that Zenetos was especially interested in taking advantage of advanced technology in order to create climatically controlled environments. Additionally, he insisted on the fact that humans would be able to do their daily activities naked. This goes hand in 
hand with his intention to provide the conditions of the cleanest, and most controllable environments possible.

To reconsider and evaluate Takis Zenetos's historically, it would be useful to place it within the history of the exchanges between architectural discipline, on the one hand, and cybernetics and automation, on the other. Some key insights on this are presented by Socrates Yiannoudes in Architecture and Adaptation: From Cybernetics to Tangible Computing [60]. Takis Zenetos's thought is very topical considering the ongoing debates about the advanced information society, especially regarding the social concerns of surveillance, governance, sovereignty within the context of Big Data. His conception of "tele-activities" provides a fertile terrain for reflecting on potential implications and insights concerning home-office conditions not only within the context of the current pandemic situation but beyond it as well. Regarding this issue, it would be interesting to relate Zenetos's thoughts concerning the shifts thanks to the home-office conditions to Aaron Benanav's key arguments is his recently published book entitled Automation and the Future of Work. An interesting distinction highlighted by Benanav in the aforementioned book is that between the "realm of necessity" and the "realm of freedom". A remark of Benanav that could be related to Zenetos's concern about "free time that will result will give a new dimension to relations between cohabiting individuals" [4] (p. 123) is the following:

The reorganization of social life to reduce the role of necessary labor is not, therefore, about overcoming work as such; it is about freeing people to pursue activities that cannot be described simply as either work or leisure. [61] (p. 91)

Relating Zenetos's views to the current debates around automation discourse and architecture would help us realise to what extent his visions are relevant within the current context. In order to contextualise Zenetos's enthusiasm regarding the liberation of the citizens thanks to the extensive use of advanced technology devices and the elimination of transportation during their daily life within the current conditions of our control societies we could relate his ideas to Alexander Galloway's reflections in Protocol: How Control Exists after Decentralization [62] and in Laruelle: Against the Digital [63]. Galloway explores the connections between Gilles Deleuze's understanding of control societies [64] and cybernetics. Adopting Deleuze and Galloway's perspective, one could interpret the freedoms to which Zenetos paid tribute as expressions of a society of control within the context of which citizens "are liberated as long as they adhere to a variety of prescribed comportments" [63] (p. 106) [65]. Despite the dangers that big data control societies entail, an ensemble of urban planning methods that are dominant today engage in order to provide a "collaborative development of urban planning and hence urban infrastructure". These tendencies, sharing Zenetos's optimism towards the flexibility offered by technology, are based on the conviction that big data offer citizens the possibility to "make connections [... ] in a more visible way and acquire more insights about the ubiquitous presence of digital and data technologies in the city" [66] (p. 377).

Funding: This research received no external funding.

Institutional Review Board Statement: Not applicable.

Informed Consent Statement: Not applicable.

Data Availability Statement: Not applicable.

Acknowledgments: The Figures included in this article are part of the Takis Ch. Zenetos Archive. I am grateful to Elina Zenetos and Constantinos Michalaros, who gave me authorization to include these images in my article.

Conflicts of Interest: The author declares no conflict of interest.

\section{References}

1. Zenetos, T. Town Planning and Electronics. Archit. Greece 1969, 3, 114-125.

2. Zenetos, T. Town Planning and Electronics. Archit. Greece 1973, 7, 112-119. 
3. Zenetos, T. City Planning and Electronics. Archit. Greece 1970, 4, 59-60.

4. Zenetos, T. Town Planning and Electronics. Archit. Greece 1974, 8, 122-135.

5. Rose, J. (Ed.) Progress of Cybernetics: Proceedings of the First International Congress of Cybernetics, London, 1969; Gordon and Breach Science Publishers: London, UK; New York, NY, USA, 1970.

6. Alexander, C. Systems Creating Systems. Archit. Des. 1968, 1/6, 90-91.

7. Pask, G. The Architectural Relevance of Cybernetics. Archit. Des. 1969, 7, 494-496.

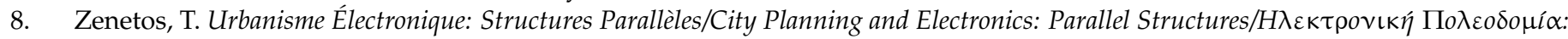

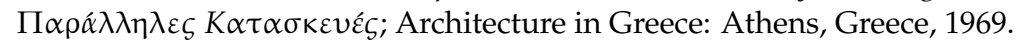

9. Cifuentes Quin, C.A. The cybernetic imagination of computational architecture. Int. J. Archit. Comput. 2016, 14, 16-29. [CrossRef]

10. Wiener, N. Cybernetics, or the Control and Communication in the Animal and the Machine; The MIT Press: Cambridge, MA, USA, 1965.

11. Spilhaus, A. Ecolibrium. Science 1972, 175, 711-715. [CrossRef]

12. Negroponte, N. Architecture Machine: Toward a More Human Environment; The MIT Press: Cambridge, MA, USA, 1973.

13. Mobile Home Report. Archit. Des. 1972, 43, 6.

14. Cook, P. Experimental Architecture; Universe Books: New York, NY, USA, 1970.

15. Middleton, R. Disintegration. Archit. Des. 1967, 37, 203-204.

16. Wurman, R.S. Making the City Observable; The MIT Press: Cambridge, MA, USA, 1971.

17. McLuhan, M. Understanding Media: The Extensions of Man; McGraw Hill: London, UK; New York, NY, USA, 1964.

18. Seaborg, G.T. Old Cities, New Cities, No Cities. Science 1972, 175, 709.

19. Zenetos, T. Myths of Low-Density Living. Archit. Des. 1973, 43, 247-248.

20. Zenetos, T. The Metro Does Not Solve Any Problem. Economy Postman 1973, 1107, 23-24; 34.

21. TCG. In The Problems of the Greater Athens Area, Athens, Proceedings of the Fifth Panhellenic Architectural Congress in Athens, Greece, 16-23 January 1974; Technical Chamber of Greece: Athens, Greece, 1974.

22. Zenetos, T. The Problems of the Greater Athens Area. Tech. Chron. 1967, 3-4, 75-90.

23. Wood, T. Labor Days: Reinventing the Workweek in the Soviet Union. Cabinet Mag. 2016, 61. Available online: https://www. cabinetmagazine.org/issues/61/wood.php (accessed on 14 January 2021).

24. Schwarz, S.M. The Continuous Working Week in Soviet Russia. Int. Labour Rev. 1931, 23, 157-180.

25. Zenetos, A. Alexandropoulos. Tele-operations: The Saving Solution. Economy Postman. 1970, 832, 7-8.

26. Zenetos. City and House of the Future. Economy Postman. 1972, 924, 10-12.

27. Buckminster Fuller, R. Nine Chains to the Moon; J.B. Lippincott Co.: Philadelphia, PA, USA; New York, NY, USA, 1938.

28. Doxiadis, C.A. Ecumenopolis: The Coming World-City. In Cities of Destiny; Toynbee, A., Ed.; Thames and Hudson: London, UK, 1967; pp. 336-358.

29. Doxiadis, C.A. Ecumenopolis: Toward a Universal City. Ekistics 1962, 13, 3-18.

30. Spatial Urbanism. Archit. Des. 1964, 76, 207.

31. Dragonas, P.; Kallipoliti, L. Silence Murmur: Detached Bodies and Cities in Takis Ch. Zenetos' Electronic Urbanism. AA Files. 2020, 77, 17-27.

32. Kallipoliti, L. Cloud Colonies: Electronic Urbanism and Takis Zenetos' City of the Future in the 1960s. ACSA Annu. Meet. Proc. 2014, 1, 678-685.

33. Greene, D. Living pod. Archigram; Cook, P., Ed.; Princeton Architectural Press: New York, NY, USA, 1999.

34. Steiner, H.A. Beyond Archigram: The Structure of Circulation; Routledge: London, UK; New York, NY, USA, 2008.

35. Papalexopoulos, D.; Kalafati, E. Takis Zenetos: Visioni Digitali, Architetture Costruite; Edilstampa: Rome, Italy, 2006.

36. Friedman, Y. Towards a Coherent System of Planning. Archit. Des. 1964, 34, 371-372.

37. Anon, F. Within the Big Structure. Archigram 1964, 5, np.

38. Suttles, G.D. The Social Construction of Communities; University of Chicago Press: Chicago, IL, USA, 1972.

39. Tamari, T. Metabolism: Utopian Urbanism and the Japanese Modern Architecture Movement. TheoryCult. Soc. 2014, 31, 201-225. [CrossRef]

40. Zhongjie Lin, Z. Metabolist Utopias and Their Global Influence: Three Paradigms of Urbanism. J. Urban Hist. 2016, 42, 604-622. [CrossRef]

41. Pernice, R. Metabolism Reconsidered Its Role in the Architectural Context of the World. J. Asian Archit. Build. Eng. 2004, 3 , 357-363. [CrossRef]

42. Kikutake, K.; Kawazoe, N.; Otaka, M.; Maki, F.; Kurokawa, K. Metabolism: The Proposals for New Urbanism; Bijutsu Shūpansha: Tokyo, Japan, 1960.

43. Eken, C.; Alpar Atun, R. The Self-Organizing City and the Architecture of Metabolism: An Architectural Critique on Urban Growth and Reorganization. Sustainability 2019, 11, 5326. [CrossRef]

44. Wigley, M. Network Fever. Grey Room. 2001, 4, 82-122. [CrossRef]

45. Herdt, T. The City and the Architecture of Change: The Work and Radical Visions of Cedric Price; Park Books: Zurich, Switzerland, 2017.

46. Banham, R. Megastructure: Urban Futures of the Recent Past; Harper and Row: New York, NY, USA, 1976.

47. Banham, R. Megastructure: Urban Futures of the Recent Past; foreword by T. Gannon; The Monacelli Press: New York, NY, USA, 2020. 
48. Gannon, T. Reyner Banham and the Paradoxes of High Tech; with an unpublished essay by Reyner Banham; The Getty Research Institute: Los Angeles, CA, USA, 2017.

49. Sadler, S. New Babylon versus Plug-in City. In Exit Utopia: Architectural Provocations 1956-76; van Schaik, M., Máčel, O., Eds.; Prestel: Munich, Germany, 2005; pp. 57-67.

50. Tzara, T. D'un certain automatisme de goût. Minotaure 1936, 9, 81-84.

51. Zenetos, T. Takis Ch. Zenetos, 1926-1977; Doumanis, O., Ed.; Architecture in Greece: Athens, Greece, 1978.

52. Otto, F. Occupying and Connecting: Thoughts on Territories and Spheres of Influence with Particular Reference to Human Settlement; Edition Axel Menges: Stuttgart, Germany; London, UK, 2009.

53. Fabricius, D. Architecture before architecture: Frei Otto's 'Deep History'. J. Archit. 2016, 21. [CrossRef]

54. Frei Otto, Note on a Drawing Entitled “What Is It?". 1984. Available online: http:/ /www.the-offbeats.com/articles/buildingtogether-the-okohaus-frei-otto-collective-improvisation/ (accessed on 14 January 2021).

55. Frei, O. Die Stadt von Morgen und das Einfamilienhaus. Baukunst Werkform 1956, 12, 642-652.

56. Friedman, Y. Towards a Mobile Architecture. Archit. Des. 1963, 33, 509-510.

57. Friedman, Y.; Orazi, M. Yona Friedman: The Dilution of Architecture; Nader, S., Ed.; Park Books: Zurich, Germany, 2015.

58. Friedman, Y. Ein Architektur-Versuch. Bauwelt 1957, 16, 361-363.

59. Koolhaas, R. Bigness or the Problem of Large; Monacelli Press: New York, NY, USA, 1995.

60. Yiannoudes, S. Architecture and Adaptation: From Cybernetics to Tangible Computing; Routledge: London, UK; New York, NY, USA, 2016.

61. Benanav, A. Automation and the Future of Work; Verso: London, UK; New York, NY, USA, 2020.

62. Galloway, A. Protocol: How Control Exists after Decentralization; The MIT Press: Cambridge, MA, USA, 2006.

63. Galloway, A. Laruelle: Against the Digital; University of Minnesota Press: Minneapolis, MN, USA, 2014.

64. Deleuze, G. Postscript on the Societies of Control. October 1992, 59, 3-7.

65. Krivý, M. Towards a critique of cybernetic urbanism: The smart city and the society of control. Plan Theory 2018, 17, 8-30. [CrossRef]

66. Ersoy, A.; Chaves Alberto, K. Understanding urban infrastructure via big data: The case of Belo Horizonte. Reg. Stud. Reg. Sci. 2019, 6, 374-379. [CrossRef] 